\title{
Supplemental vitamin A enhances the recovery from iron deficiency in rats with chronic vitamin A deficiency
}

\author{
BY ANNET J.C. ROODENBURG ${ }^{1,2}$, CLIVE E. WEST ${ }^{1,3}$, ROBERT HOVENIER ${ }^{1}$ \\ AND ANTON C. BEYNEN ${ }^{2}$ \\ ${ }^{1}$ Department of Human Nutrition, Wageningen Agricultural University, Wageningen, \\ The Netherlands \\ ${ }^{2}$ Department of Laboratory Animal Science, State University Utrecht, The Netherlands \\ ${ }^{3}$ Center for International Health, Rollins School of Public Health, Emory University, \\ 1518 Clifton Road N.E., Atlanta GA 30322, USA
}

(Received 29 September 1993 - Revised 25 April 1995-Accepted 16 August 1995)

\begin{abstract}
Studies with anaemic children and pregnant women from areas where vitamin $A$ deficiency is endemic have shown a beneficial effect on Fe status of supplemental vitamin $A$ in addition to Fe supplementation. This suggests a relationship between vitamin $A$ and $F e$ status, which we attempted to mimic in rats with anaemia and chronic vitamin $A$ deficiency. Male rats were fed on Fe-adequate diets $(35 \mathrm{mg} \mathrm{Fe} / \mathrm{kg})$ containing different levels of vitamin $A(1200,450,150,75$ and 0 retinol equivalents (RE)/ $\mathrm{kg}$ feed) until they were 5 weeks old. These diets were identical to the diets fed to their mothers. Then the young male rats were transferred to diets containing the same levels of vitamin $A$ but no added Fe. After another 2 weeks the rats were repleted with $\mathrm{Fe}(35 \mathrm{mg} / \mathrm{kg}$ feed) without or with vitamin A to a level of $1200 \mathrm{RE} / \mathrm{kg}$ feed. Increased vitamin $A$ intake by the groups previously fed on diets with either 0 or $75 \mathrm{RE} / \mathrm{kg}$ produced a reduction in blood haemoglobin concentration, packed cell volume and erythrocyte count. In the group which had been fed on the diet without vitamin A, supplemental vitamin $A$ raised mean cell volume, plasma Fe concentration and total Fe-binding capacity. Vitamin A supplementation during the period of Fe repletion produced a decrease in splenic and tibia Fe concentration, the effect being greater with increasing severity of previous vitamin A deficiency. The paradoxical effect of supplemental vitamin $A$ on haemoglobin, packed cell volume and erythrocyte count can be explained by a decrease in the degree of haemoconcentration. Thus, the positive effect of supplemental vitamin A seen in humans is also observed with rats under controlled experimental conditions. We speculate that supplemental vitamin $A$ during Fe repletion contributes to optimum erythropoiesis and Fe mobilization when baseline vitamin $A$ status is impaired.
\end{abstract}

Vitamin A: Iron: rats

In children (Mejía \& Arroyave, 1982; Bloem et al. 1989; Wolde-Gebriel et al. 1993a, b) and pregnant women (Suharno et al. 1992) from areas where vitamin A deficiency is endemic, low plasma retinol levels are associated with low concentrations of haemoglobin and serum Fe and low degrees of transferrin saturation. When children with relatively low blood haemoglobin levels $(<7.5 \mathrm{mmol} / \mathrm{l})$ were supplemented with vitamin A the haemoglobin levels rose (Mohanram et al. 1977; Mejía \& Chew, 1988; Muhilal et al. 1988; Bloem et al. 1989, 1990). Interestingly, when vitamin A was given together with $\mathrm{Fe}$ as compared with Fe supplementation alone, not only serum $\mathrm{Fe}$ concentration and transferrin saturation (Mejía \& Chew, 1988) but also blood haemoglobin levels (Suharno et al. 1993) rose to higher values. Thus, there appears to be an additional effect of vitamin $\mathrm{A}$ on Fe metabolism during the recovery from Fe deficiency.

In order to investigate the mechanisms underlying the relationship between vitamin $A$ 
and Fe status, experiments with animals are required. In rats, vitamin A deficiency impairs erythropoiesis (Amine et al. 1970; Mejía et al. 1979 b) and raises the concentrations of Fe in liver (Mejía et al. 1979a; Staab et al. 1984; Sklan et al. 1986; Sijtsma et al. 1993) and spleen (Mejía et al. $1979 a$; Roodenburg et al. 1994), but generally lowers the total amount of Fe in liver (Sijtsma et al. 1993; Roodenburg et al. 1994). The effect of vitamin A supplementation on dietary-Fe-induced regeneration of Fe status has not yet been studied in rats. It was hypothesized that this effect of vitamin A depends on the vitamin A status of the rats. Thus, we determined Fe variables in blood and organs of anaemic rats with various degrees of chronic vitamin A deficiency before and after supplementation with vitamin $\mathrm{A}$ together with $\mathrm{Fe}$. It was anticipated that this study would provide clues as to the underlying mechanisms of the additional effect of vitamin A on Fe status, as found in Fesupplementation studies with children and pregnant women.

\section{MATERIALS AND METHODS}

The experiment was approved and supervised by the animal welfare officer of Wageningen Agricultural University.

\section{Animals, housing and diets}

A controlled light-dark cycle (light on: $06.00-18.00$ hours), temperature $\left(20-22^{\circ}\right)$ and relative humidity $(50-60 \%)$ were maintained in the animal room. All animals had free access to feed and demineralized water throughout.

Fifty-two female and twenty-eight male Wistar rats (Cpb:WU), aged 10 weeks, were used for breeding. The rats were housed in groups of four or five animals of the same sex in stainless steel cages with wire mesh bases $(300 \times 420 \times 190 \mathrm{~mm})$. During a period of 4 weeks, all animals received a control diet (Table 1) containing sufficient vitamin A (1200 retinol equivalents (RE) $/ \mathrm{kg}$ feed). This diet was formulated according to the nutrient requirements of rats (National Research Council, 1978). Then, 2 weeks before mating, the female rats were divided into five groups matched for body weight, and transferred to wiretopped, polycarbonate cages $(345 \times 225 \times 160 \mathrm{~mm})$ with a layer of sawdust as bedding. They were housed one or two per cage. The groups received diets with different levels of vitamin $\mathrm{A}(1200,450,150,75$ or $0 \mathrm{RE} / \mathrm{kg}$ feed). The purified diets (Table 1) were pelleted (diameter $10 \mathrm{~mm}$ ). Male rats continued to receive the control diet. For mating, one male rat was housed together with one or two females, aged 16 weeks, for a period of $10 \mathrm{~d}$. After this period the female rats were housed individually in the polycarbonate cages until the pups were weaned. All female rats appeared healthy and body weights and litter size were similar for the five groups. From each group, sixteen male pups entered the preexperimental period at about 3 weeks of age. The pups were born 24-29 d after the start of temporary cohabiting of the males and females.

\section{Pre-experimental period}

The pups were housed in groups of four animals in stainless steel cages with wire mesh bases $(300 \times 420 \times 190 \mathrm{~mm})$. The rats were randomly assigned to the cages which were distributed uniformly over the animal room. For a period of 2 weeks (days -28 to -14 ) the rats were fed on the same diet as their respective mothers (Fig. 1), except that the diets were in powdered form. Then (day -14), when the rats were 5 weeks old, a blood sample was taken for haematological examination and analysis of plasma retinol concentration. Body weight, feed intake and haematological characteristics at day -14 (Fig. 1) are shown in Table 2. Haemoglobin concentration, packed cell volume and erythrocyte count were increased in the groups given either the diets without added vitamin A or with $75 \mathrm{RE} / \mathrm{kg}$. This corroborates earlier work (Koessler et al. 1926; Mejía et al. 1979a) and is explained 
Table 1. Composition of the diets*

\begin{tabular}{lc}
\hline \hline Ingredients & \\
\hline Casein $(\mathrm{g})$ & 151 \\
Maize oil (g) & 25 \\
Coconut fat (g) & 25 \\
Glucose (g) & $709 \cdot 2$ \\
Cellulose (g) & 30 \\
$\mathrm{CaCO}_{3}(\mathrm{~g})$ & $12 \cdot 4$ \\
$\mathrm{NaH}_{2} \mathrm{PO}_{4} .2 \mathrm{H}_{2} \mathrm{O}(\mathrm{g})$ & $15 \cdot 1$ \\
$\mathrm{MgCO}_{3}(\mathrm{~g})$ & $1 \cdot 4$ \\
$\mathrm{KCl}(\mathrm{g})$ & $1 \cdot 0$ \\
$\mathrm{KHCO}_{3}(\mathrm{~g})$ & $7 \cdot 7$ \\
$\mathrm{FeSO}_{4} .7 \mathrm{H}_{2} \mathrm{O}(\mathrm{mg})$ & $174 / 0$ \\
Vitamin A preparation (retinol equivalents, $\mathrm{RE}) \dagger$ & $0 / 75 / 150 / 450 / 1200$ \\
Mineral premix (iron-free) $\dagger(\mathrm{g})$ & 10 \\
Vitamin premix (vitamin A-free)§ (g) & 12 \\
\hline
\end{tabular}

* The diets were in powdered form. The breeder rats were given the diets in pelleted form with the same composition, except that per $\mathrm{kg}$ feed $379.6 \mathrm{~g}$ glucose was replaced by $329.6 \mathrm{~g}$ maize starch plus $50 \mathrm{~g}$ molasses. The amount of $\mathrm{Fe}$ added to the pelleted diet $\left(124 \mathrm{mg} \mathrm{FeSO} \mathrm{F}_{4} .7 \mathrm{H}_{2} \mathrm{O}\right)$ was corrected for the $\mathrm{Fe}$ content of molasses.

$\uparrow$ Rovimix A 500\$, $150 \mathrm{RE} / \mathrm{mg}$ (F. Hoffman-La Roche \& Co. Ltd, Basle, Switzerland), consisting of retinyl acetate and retinyl palmitate; of this preparation $1200,450,150,75,0 \mathrm{RE} / \mathrm{kg}$ feed was added.

\$ The mineral premix consisted of (mg): $\mathrm{MnO}_{2} 79, \mathrm{ZnSO}_{4} \cdot \mathrm{H}_{2} \mathrm{O} 33, \mathrm{NiSO}_{4} \cdot 6 \mathrm{H}_{2} \mathrm{O} 13, \mathrm{NaF} 2, \mathrm{KI} 0.2$, $\mathrm{CuSO}_{4} .5 \mathrm{H}_{2} \mathrm{O} 15 \cdot 7, \mathrm{Na}_{2} \mathrm{SeO}_{3} .5 \mathrm{H}_{2} \mathrm{O} 0 \cdot 3, \mathrm{CrCl}_{3}, 6 \mathrm{H}_{2} \mathrm{O} 1 \cdot 5, \mathrm{SnCl}_{2} \cdot 2 \mathrm{H}_{2} \mathrm{O} 1 \cdot 9, \mathrm{NH}_{4} \mathrm{VO}_{3} 0 \cdot 2$, maize meal 9853-2.

$\S$ The vitamin premix consisted of $(\mathrm{mg})$ : thiamin 4 , riboflavin 3 , niacin $20, \mathrm{D}, \mathrm{L}$-calcium pantothenate 17.8 , pyridoxine 6 , cyanocobalamin 50 , choline chloride 2000 , pteroylmonoglutamic acid 1 , biotin 2 , menadione 0.05 , $\mathrm{D}, \mathrm{L}-\alpha$-tocopheryl acetate 60 , cholecalciferol 2, maize meal $9834 \cdot 15$.

by haemoconcentration due to chronic vitamin A deficiency (Koessler et al. 1926; McLaren et al. 1965; Mejía et al. 1979a,b). On day -14 (Fig. 1) the rats receiving the diet with $1200 \mathrm{RE} / \mathrm{kg}$ were divided into two groups of eight animals each, which were matched for body weight and haemoglobin concentration. One group of eight animals (reference group) continued to be fed on the control diet. The other group (control group) received the same diet but without added Fe. All other groups were deprived of added dietary $\mathrm{Fe}$ but continued to receive their respective levels of dietary vitamin A as illustrated in Fig. 1.

After another $14 \mathrm{~d}$ (day 0), another blood sample was taken for the same measurements as above. Table 3 shows a similar pattern of results as does Table 2, except that body weights were lowered with decreasing vitamin A intakes in the Fe-depleted groups. When compared with the reference group, Fe depletion for $14 \mathrm{~d}$ produced low haemoglobin concentrations in all groups except for the one given the diet without added vitamin A. Apparently, the progression of haemoconcentration caused by vitamin-A deficiency had counteracted the decrease in blood haemoglobin concentration caused by Fe deficiency.

\section{Supplementation trial}

The Fe and/or vitamin A repletion was introduced on day 0 of the experiment (Fig. 1). The Fe-deficient groups receiving the diets with either $450,150,75$ or $0 \mathrm{RE} / \mathrm{kg}$ were each divided into two groups of eight animals, which were stratified within dietary vitamin A level for haemoglobin concentration and body weight both measured on day 0 (Fig. 1). All animals received $\mathrm{Fe}$ again $(35 \mathrm{mg} / \mathrm{kg}$ feed), but half of the animals continued to receive the reduced levels of vitamin $\mathrm{A}$, whereas the other half were supplemented with $1200 \mathrm{RE} / \mathrm{kg}$ feed. The reference group remained on the control diet. The rats that had been fed on the diet containing $1200 \mathrm{RE} / \mathrm{kg}$ feed but without added $\mathrm{Fe}$ were transferred to the $\mathrm{Fe}$-adequate 


\begin{tabular}{|c|c|c|c|}
\hline \multirow{2}{*}{$\begin{array}{l}1200 \mathrm{RE} \\
35 \mathrm{mg} \mathrm{Fe}\end{array}$} & $\begin{array}{c}1200 \mathrm{RE} \\
35 \mathrm{mg} \mathrm{Fe} \\
\end{array}$ & $\begin{array}{c}1200 \mathrm{RE} \\
35 \mathrm{mg} \mathrm{Fe} \\
\end{array}$ & \multirow{2}{*}{$\begin{array}{l}\text { Reference } \\
\text { Control }\end{array}$} \\
\hline & $\begin{array}{l}1200 \mathrm{RE} \\
0 \mathrm{mg} \mathrm{Fe}\end{array}$ & $\begin{array}{l}1200 \mathrm{RE} \\
35 \mathrm{mg} \mathrm{Fe}\end{array}$ & \\
\hline \multirow{2}{*}{$\begin{array}{l}450 \mathrm{RE} \\
35 \mathrm{mg} \mathrm{Fe}\end{array}$} & \multirow{2}{*}{$\begin{array}{l}450 \mathrm{RE} \\
0 \mathrm{mg} \mathrm{Fe}\end{array}$} & $\begin{array}{c}1200 \mathrm{RE} \\
35 \mathrm{mg} \mathrm{Fe}\end{array}$ & \\
\hline & & $\begin{array}{r}450 \mathrm{RE} \\
35 \mathrm{mg} \mathrm{Fe}\end{array}$ & \\
\hline \multirow{2}{*}{$\begin{array}{l}150 \mathrm{RE} \\
35 \mathrm{mg} \mathrm{Fe}\end{array}$} & \multirow{2}{*}{$\begin{array}{l}150 \mathrm{RE} \\
0 \mathrm{mg} \mathrm{Fe}\end{array}$} & $\begin{array}{c}1200 \mathrm{RE} \\
35 \mathrm{mg} \mathrm{Fe}\end{array}$ & \\
\hline & & $\begin{array}{c}150 \mathrm{RE} \\
35 \mathrm{mg} \mathrm{Fe}\end{array}$ & \\
\hline \multirow{2}{*}{$\begin{array}{l}75 \mathrm{RE} \\
35 \mathrm{mg} \mathrm{Fe}\end{array}$} & \multirow{2}{*}{$\begin{array}{l}75 \mathrm{RE} \\
0 \mathrm{mg} \mathrm{Fe}\end{array}$} & $\begin{array}{l}1200 \mathrm{RE} \\
35 \mathrm{mg} \mathrm{Fe}\end{array}$ & \\
\hline & & $\begin{array}{l}75 \mathrm{RE} \\
35 \mathrm{mg} \mathrm{Fe}\end{array}$ & \\
\hline \multirow{2}{*}{$\begin{array}{c}0 \mathrm{RE} \\
35 \mathrm{mg} \mathrm{Fe}\end{array}$} & \multirow{2}{*}{$\begin{array}{l}0 \mathrm{RE} \\
0 \mathrm{mg} \mathrm{Fe}\end{array}$} & $\begin{array}{c}1200 \mathrm{RE} \\
35 \mathrm{mg} \mathrm{Fe}\end{array}$ & \\
\hline & & $\begin{array}{c}0 \mathrm{RE} \\
35 \mathrm{mg} \mathrm{Fe}\end{array}$ & \\
\hline & & & 10 Time (days) \\
\hline \multicolumn{2}{|c|}{ ental period } & $\begin{array}{l}\text { Supplemen- } \\
\text { tation trial }\end{array}$ & \\
\hline
\end{tabular}

Fig. 1. Experimental design: except for the reference group (top bar) the rats with different vitamin A status went through an iron-depletion period (days -14 to 0 ) followed by an iron-repletion period without or with vitamin A supplementation. At weaning on day -28 the rats were 3 weeks old. Before weaning the pups were raised by dams that had been fed since 2 weeks before mating on the same diets the pups were to be given at weaning. The rats were killed on day 10 for the removal of tissues. The number of rats per group on days -28 and -14 , was sixteen and on day 10 it was eight. The diets used differed only in vitamin $A$ and iron content (Table 1); the amounts are indicated are retinol equivalents (RE) and $\mathrm{mg} \mathrm{Fe} / \mathrm{kg}$ feed.

control diet again. After another $10 \mathrm{~d}$ (day 10), all animals were killed. Throughout the supplementation trial, body weight and feed intake were monitored.

\section{Collection of samples}

Blood was collected, in heparinized vials, by orbital puncture while the rats were under diethyl ether anaesthesia. In our hands the orbital puncture technique itself does not affect the endocrine stress response and induces lesions that heal without detectable scars (Van Herck et al. 1991, 1992). The blood was stored at $0^{\circ}$ for haematological examination on the same day. Then plasma was isolated by centrifugation $(10 \mathrm{~min}, 3000 \mathrm{rev} . / \mathrm{min})$ and stored at $-20^{\circ}$ until analysis, except for $250 \mu \mathrm{l}$ which was stored at $-80^{\circ}$ for subsequent analysis of retinol. Immediately after bleeding, the anaesthetized rats were decapitated. The left kidney, liver, spleen and both hindlegs were removed and stored at $-20^{\circ}$ until analysis. Organs were weighed before storage.

\section{Chemical analyses}

Haemoglobin concentration, packed cell volume, erythrocyte count and mean cell volume were analysed with a blood cell counter (Model K-1000, Sysmex, IJsselstein, The Netherlands). Plasma Fe concentrations and total Fe-binding capacity were determined spectrophotometrically using a commercial test kit (Roche Nederland, Mijdrecht, The Netherlands). Spleen and liver were washed with saline $(9 \mathrm{~g} \mathrm{NaCl} / \mathrm{l})$ and liver was homogenized as described below. Liver homogenate, spleen, kidney and tibia were dried 
Table 2. Body weight, feed intake, plasma retinol concentrations and haematological characteristics at day -14 in rats fed on diets containing different levels of vitamin $A \dagger$

(Mean values with their pooled standard errors for sixteen animals per group)

\begin{tabular}{|c|c|c|c|c|c|c|c|c|}
\hline \multirow{2}{*}{$\begin{array}{l}\text { Dietary } \\
\text { vitamin A } \\
(\mathrm{RE} / \mathrm{kg})\end{array}$} & \multirow{2}{*}{$\begin{array}{l}\text { Body wt } \\
\text { (g) }\end{array}$} & \multirow{2}{*}{$\begin{array}{l}\text { Feed } \\
\text { intake } \\
(\mathrm{g} / \mathrm{d}) \ddagger\end{array}$} & \multicolumn{2}{|c|}{$\begin{array}{c}\text { Plasma } \\
\text { retinol } \\
(\mu \mathrm{mol} / \mathrm{l}) \S\end{array}$} & \multirow{2}{*}{$\begin{array}{l}\text { Haemoglobin } \\
(\mathrm{mmol} / 1)\end{array}$} & \multirow{2}{*}{$\begin{array}{l}\text { Packed cell } \\
\text { volume } \\
(\%)\end{array}$} & \multirow{2}{*}{$\begin{array}{c}\text { Erythrocyte } \\
\text { count } \\
(10 \mathrm{E} 12 / 1)\end{array}$} & \multirow{2}{*}{$\begin{array}{l}\text { Mean cel } \\
\text { volume } \\
\text { (fi) }\end{array}$} \\
\hline & & & Mean & $\mathrm{SE}$ & & & & \\
\hline 1200 & 145.5 & 16.9 & $2 \cdot 55$ & $0 \cdot 05$ & $7 \cdot 9$ & $39 \cdot 8$ & 5.75 & $69 \cdot 3$ \\
\hline 450 & $141 \cdot 7$ & $16 \cdot 8$ & 1.92 & 0.09 & $7 \cdot 9$ & $40 \cdot 6$ & $5 \cdot 67$ & $71 \cdot 6^{*}$ \\
\hline 150 & 133.5 & $16 \cdot 3$ & $1.08^{*}$ & $0 \cdot 12$ & $8 \cdot 1$ & $41 \cdot 7^{*}$ & $5 \cdot 87$ & $71 \cdot 1$ \\
\hline 75 & $135 \cdot 2$ & $15 \cdot 8$ & $0.60^{*}$ & $0 \cdot 12$ & $8 \cdot 2^{*}$ & $41 \cdot 9 *$ & $6 \cdot 12^{*}$ & 68.6 \\
\hline 0 & 141.6 & $15 \cdot 8$ & $0.23^{*}$ & 0.02 & $8.5^{*}$ & $43 \cdot 7^{*}$ & $6 \cdot 29^{*}$ & 69.4 \\
\hline Pooled SE & 3.4 & - & - & - & 0.1 & 0.4 & 0.10 & 0.6 \\
\hline \multicolumn{9}{|c|}{$P$ values for trend effects of vitamin $A$ intake } \\
\hline $\mathbf{L}$ term & 0.044 & - & \multirow{2}{*}{\multicolumn{2}{|c|}{$\begin{array}{l}<0.001 \\
<0.001\end{array}$}} & $<0.001$ & $<0.001$ & $<0.001$ & $>0.05$ \\
\hline$Q$ term & $>0.05$ & - & & & $<0.001$ & 0.004 & $<0.001$ & $<0.001$ \\
\hline
\end{tabular}

RE, retinol equivalents.

* Mean values were significantly different from those for the group given $1200 \mathrm{RE} / \mathrm{kg}, P<0.0125$ (Student's $t$ test).

$\uparrow$ For details of diets and procedures, see Table 1 and pp. 624-629.

$\$$ Feed intake was measured per cage with four animals from day -28 to -14 (Fig. 1); the pooled SE was not calculated because of the low number of degrees of freedom.

$\S$ Before statistical analysis the data were log-transformed (unadjusted means and separate sE are given).

$\|$ Value for linear (L) and/or quadratic (Q) term in effect of vitamin A intake.

$\left(100^{\circ}, 12 \mathrm{~h}\right)$ and ashed $\left(500^{\circ}, 16 \mathrm{~h}\right)$. The ash was dissolved in $1 \mathrm{ml} 6 \mathrm{M}-\mathrm{HCl}$ and diluted with demineralized water. Fe was measured by flame atomic absorption spectrometry (Model AA-475, Varian, Springvale, Australia). All analyses were carried out singly. Fe in tibia was calculated as the mean of left and right tibia.

Plasma and liver retinol concentrations were measured by reversed phase HPLC. Plasma $(100 \mu \mathrm{l})$ was mixed vigorously with ethanol $(900 \mathrm{ml} / \mathrm{l}, 400 \mu \mathrm{l})$ and, after centrifuging (3000 rev./min, $10 \mathrm{~min}$ ), retinol was determined directly in the supernatant fraction and calibrated against solutions of retinol in ethanol $(720 \mathrm{ml} / \mathrm{l})$. Serum pools with retinol concentrations of 0.63 or $2.16 \mu \mathrm{mol} / 1$ were used as external controls. The combined between- and within-run variations of retinol determination in the two pools were $6 \%$ and $4 \%$ (CV). The particulars of the HPLC system used were as follows: injection volume, $50 \mu 1$; pre-column, $10 \times 3 \mathrm{~mm}$ stainless steel packed with Chromguard reversed phase (Chrompack, Middelburg, The Netherlands); column, $100 \times 3 \mathrm{~mm}$ glass cartridge packed with Spherisorb-ODS $(5 \mu \mathrm{m})$ (Chrompack); isocratic pump (Spectra Physics, San Jose, CA, USA); UV/vis detector (Perkin Elmer, Norwalk, CO, USA) with wavelength of $325 \mathrm{~nm}$; mobile phase, methanol-water $(90: 10, \mathrm{v} / \mathrm{v})$; flow rate, $0.4 \mathrm{ml} / \mathrm{min}$; run time, 5 min; retention time, $3.5 \mathrm{~min}$.

Liver total retinol was determined after saponification and extraction. Liver homogenate $(200 \mu \mathrm{l})$ (liver-demineralized water, 1:5, w/v) was digested by heating at $100^{\circ}$ for $15 \mathrm{~min}$ in $1500 \mu 10.7 \mathrm{M}-\mathrm{KOH}$ in ethanol $(500 \mathrm{ml} / \mathrm{l}$ ) (containing $6 \mathrm{~g}$ pyrogallol/1), and after cooling the mixture was extracted twice with $4 \mathrm{ml}$ hexane. Standards with retinol acetate in absolute ethanol were processed identically and used for calibration. After centrifugation ( $3000 \mathrm{rev} / \mathrm{min}, 6 \mathrm{~min}$ ), the upper layer of the hexane extract was collected and retinol determined using the HPLC method described above, except for the following conditions: 
Table 3. Body weight, feed intake, plasma retinol concentrations and haematological characteristics after an iron depletion period (day 0$)$ in rats fed on different levels of vitamin $A^{\dagger}$

(Mean values for eight animals in the reference and control groups and sixteen animals for all other groups. Pooled standard errors are calculated for eight animals per group)

\begin{tabular}{|c|c|c|c|c|c|c|c|c|}
\hline \multirow{2}{*}{$\begin{array}{l}\text { Dietary } \\
\text { vitamin A } \\
(\mathrm{RE} / \mathrm{kg})\end{array}$} & \multirow{2}{*}{$\begin{array}{l}\text { Body wt } \\
\text { (g) }\end{array}$} & \multirow{2}{*}{$\begin{array}{c}\text { Feed } \\
\text { intake } \\
(\mathrm{g} / \mathrm{d}) \ddagger\end{array}$} & \multicolumn{2}{|c|}{$\begin{array}{c}\text { Plasma } \\
\text { retinol } \\
(\mu \mathrm{mol} / 1) \S\end{array}$} & \multirow{2}{*}{$\begin{array}{l}\text { Haemoglobin } \\
(\mathrm{mmol} / \mathrm{l})\end{array}$} & \multirow{2}{*}{$\begin{array}{l}\text { Packed cell } \\
\text { volume } \\
(\%)\end{array}$} & \multirow{2}{*}{$\begin{array}{l}\text { Erythrocyte } \\
\text { count } \\
(10 \mathrm{E} 12 / 1)\end{array}$} & \multirow{2}{*}{$\begin{array}{l}\text { Mean cell } \\
\text { volume } \\
\text { (fl) }\end{array}$} \\
\hline & & & Mean & SE & & & & \\
\hline $\begin{array}{l}1200 \\
\text { (reference) } \|\end{array}$ & $227 \cdot 2$ & $17 \cdot 1$ & $2 \cdot 28$ & 0.03 & $8.8 * *$ & $44 \cdot 0^{* *}$ & $6 \cdot 42^{* *}$ & $68 \cdot 6^{* *}$ \\
\hline $\begin{array}{l}1200 \\
\text { (control) }\end{array}$ & $224 \cdot 9$ & $17 \cdot 1$ & $2 \cdot 16$ & 0.06 & 6.9 & $35 \cdot 3$ & 5.95 & $59 \cdot 3$ \\
\hline 450 & $219 \cdot 9$ & $16 \cdot 7$ & $1 \cdot 64$ & 0.05 & 6.7 & $34 \cdot 4$ & 5.75 & $59 \cdot 7$ \\
\hline 150 & $198 \cdot 7^{* *}$ & $14 \cdot 5$ & $0.72^{* *}$ & 0.05 & $7 \cdot 4$ & 37.9 & 6.20 & 61.0 \\
\hline 75 & $200 \cdot 2^{* *}$ & $14 \cdot 4$ & $0 \cdot 36^{* *}$ & 0.05 & $7 \cdot 4$ & $37 \cdot 3$ & 6.33 & 58.9 \\
\hline 0 & $173 \cdot 4^{* *}$ & $8 \cdot 4$ & $0.05^{* *}$ & 0.01 & $8 \cdot 3^{* *}$ & $42 \cdot 3^{* *}$ & $7.06 * *$ & 59.9 \\
\hline Pooled SE & $6 \cdot 1$ & - & - & - & 0.2 & $0 \cdot 9$ & $0 \cdot 12$ & 0.7 \\
\hline \multicolumn{9}{|c|}{$P$ values for trend effects $\Phi$} \\
\hline $\begin{array}{l}\mathrm{L} \text { term: } \\
Q \text { term: }\end{array}$ & $\begin{array}{l}<0.001 \\
<0.001\end{array}$ & - & \multicolumn{2}{|c|}{$\begin{array}{l}<0.001 \\
<0.001\end{array}$} & $\begin{array}{l}<0-001 \\
<0-001\end{array}$ & $\begin{array}{l}<0.001 \\
<0.001\end{array}$ & $\begin{array}{l}<0.001 \\
<0.001\end{array}$ & $\begin{array}{l}>0.05 \\
>0.05\end{array}$ \\
\hline $\begin{array}{l}\text { Iron } \\
\text { intake: }\end{array}$ & $>0.05$ & - & \multicolumn{2}{|c|}{$>0.05$} & $<0.001$ & $<0.001$ & 0.008 & $<0.001$ \\
\hline
\end{tabular}

$\mathrm{RE}$, retinol equivalents.

** Mean values were significantly different from those for the control group, $P<0 \cdot 01$.

$\uparrow$ For details of diets and procedures, see Table 1 and pp. 624-629.

$\$$ Feed intake was measured per cage with four animals from day -14 to 0 (Fig. 1); the pooled SE was not calculated because of the low number of degrees of freedom.

$\S$ Before statistical analysis the data were log-transformed (unadjusted means and separate SE are given).

\| The reference group was the only one receiving Fe with the diet $(35 \mathrm{mg} / \mathrm{kg})$ from days -14 to 0 .

ๆ Values for linear (L) and/or quadratic (Q) term in effect of vitamin A intake and iron intake.

injection volume, $20 \mu 1$; mobile phase, methanol-water $(95: 5, \mathrm{v} / \mathrm{v})$; flow rate, $0.4 \mathrm{ml} / \mathrm{min}$; run time, $3 \mathrm{~min}$; retention time, $1.6 \mathrm{~min}$. Recovery, as determined by adding known amounts of retinol acetate to homogenates before digestion, was $90-95 \%$. A pooled liver homogenate with target value of $98 \mu \mathrm{mol}$ retinol $/ 1$ was used as an external control. The combined between- and within-run variation of retinol determination was $6 \%(\mathrm{CV})$.

\section{Statistical analysis}

Estimated values of the components of variance of cage and litter were calculated from the mean squares (Snedecor \& Cochran, 1980) and compared with the mean squared errors. They were all considerably smaller than the residual variance, except for six variables (body weight at days $-14,0$ and 10, erythrocyte count at day -14, Fe in kidney and tibia at day $10)$ of which the cage component of variance was of similar size. We therefore ignored any litter or cage component of variance.

The data for the two pre-experimental time points (days -14 and $0 ;$ Fig. 1) and the time point at the end of the supplementation trial (day 10) were evaluated by one-way ANOVA with vitamin A intake as factor. If variances were not homogeneous (Cochran's C test), data were log-transformed before statistical testing. Contrasts with standard errors 
calculated from pooled variances were used to identify statistically significant differences. A pre-set $\boldsymbol{P}$ value of 0.05 with Bonferroni's adaptation was used for controlling the experiment-wise error rate of any set of eight comparisons with the control group (effect of differences in vitamin $A$ intake in pre-experimental period) or of any set of four pair-wise comparisons relating to the effect of vitamin A supplementation during the experimental period. In addition, linear contrasts were used to test polynomial (linear and quadratic) regressions on measurement values at days -14 and 0 and day 10 against previous (before day 0) vitamin A intake. This analysis was also carried out for the day 10 values in the groups given $450,150,75$ or $0 \mathrm{RE} / \mathrm{kg}$ with supplemental vitamin A as extra independent variable. For the day 0 values in all the six groups dietary Fe was added as independent variable in the trend analysis.

\section{RESULTS}

\section{Body weight, feed intake and organ weights}

For the reference group ( $n 8)$ which received the diet with $1200 \mathrm{RE}$ and $35 \mathrm{mg} \mathrm{Fe} / \mathrm{kg}$ throughout (Fig. 1), the following values were obtained: body weight, $266.9 \mathrm{~g}$; feed intake $/ \mathrm{d}, 16.83 \mathrm{~g}$; liver wet weight, $11.2 \mathrm{~g}$; spleen wet weight, $0.43 \mathrm{~g}$; kidney wet weight, $0.77 \mathrm{~g}$; pooled SE are given in Table 4. After Fe repletion for $10 \mathrm{~d}$, body and liver weights in the rats fed on the diets with less than $450 \mathrm{RE} / \mathrm{kg}$ remained depressed when compared with the control group, irrespective of vitamin A supplementation (Table 4). Supplemental vitamin A only raised body and organ weights in the group that had been deprived of vitamin A until day 0 . These effects were associated with an increase in feed intake (Table 4). In the rats fed on diets without added vitamin $A$ throughout, there was no body-weight gain during the Fe-repletion period (Tables 3 and 4). In these animals, liver, spleen and kidney weights were also markedly lower (Table 4). For the groups with dietary vitamin A concentrations lower than $1200 \mathrm{RE} / \mathrm{kg}$ feed before day 0 , previous vitamin $\mathrm{A}$ intake and supplemental vitamin A significantly influenced body and organ weights as based on the trend analysis.

\section{Vitamin A status}

The differences in plasma retinol levels between the four groups deficient in vitamin A (Table 3) were maintained during Fe repletion but not during vitamin A supplementation from days $0-10$ (Fig. 2) and were reflected in the liver retinol concentrations at day 10 (Table 5). In fact, no retinol was detectable in the livers of the groups fed on diets with $150 \mathrm{RE} / \mathrm{kg}$ or less. The reference group fed on the diet with $1200 \mathrm{RE}$ and $35 \mathrm{mg} \mathrm{Fe}$ throughout had a mean liver retinol concentration of 54.3 (SE 3.6) nmol/g wet weight. Vitamin A supplementation increased both liver and serum retinol levels significantly although the final values remained below those seen in the rats maintained on a diet adequate in vitamin A throughout. Plasma retinol concentrations were $2 \cdot 15$ (SE 0.04) and 2.08 (SE 0.09) $\mu \mathrm{mol} / 1$ for the reference group $(n 8)$ and the control group $(n 8)$ respectively.

\section{Haematology}

Fe repletion during days 0 to 10 produced increases in haematological variables (Tables 3 and 6). In the groups fed on either the diet without vitamin A or with $75 \mathrm{RE} / \mathrm{kg}$, haemoglobin, packed cell volume and erythrocyte count at day 10 (Table 6) were higher than in their counterparts repleted with vitamin A. Mean cell volume was lowest in the rats maintained on the diet without vitamin A but supplementation resulted in an increase (Table 6). Trend analysis for the groups with dietary vitamin A concentrations of $0-450 \mathrm{RE} / \mathrm{kg}$ until day 0 had the following outcome. Previous vitamin A intake significantly influenced erythrocyte count and mean cell volume, and supplemental vitamin 
Table 4. Body weight, feed intake and organ weights at day 10 for rats fed on diets containing different levels of vitamin $A \ddagger$

(Mean values with their pooled standard errors for eight animals per group; the calculation of the pooled SE included the reference group)

\begin{tabular}{|c|c|c|c|c|c|}
\hline \multirow[b]{2}{*}{$\begin{array}{l}\text { Dietary vitamin } \mathrm{A} \text { (before day } \\
0 \text { - after day } 0, \mathrm{RE} / \mathrm{kg} \text { ) }\end{array}$} & \multirow[b]{2}{*}{$\begin{array}{l}\text { Body wt } \\
\text { (g) }\end{array}$} & \multirow[b]{2}{*}{$\begin{array}{l}\text { Feed intake } \\
\qquad(\mathrm{g} / \mathrm{d}) \S\end{array}$} & \multicolumn{3}{|c|}{ Organ wet wt } \\
\hline & & & $\begin{array}{l}\text { Liver } \\
\text { (g) }\end{array}$ & $\begin{array}{l}\text { Spleen } \\
\quad(\mathrm{g})\end{array}$ & $\begin{array}{l}\text { Kidney } \\
(\mathrm{g})\end{array}$ \\
\hline $1200-1200$ (control) & $272 \cdot 3$ & 18.59 & $11 \cdot 0$ & 0.46 & 0.82 \\
\hline $\begin{array}{l}450-1200 \\
450-450\end{array}$ & $\begin{array}{l}272 \cdot 6 \\
269 \cdot 1\end{array}$ & $\begin{array}{l}18 \cdot 63 \\
18 \cdot 84\end{array}$ & $\begin{array}{l}10 \cdot 6 \\
10 \cdot 8\end{array}$ & $\begin{array}{l}0.45 \\
0.49\end{array}$ & $\begin{array}{l}0.81 \\
0.85\end{array}$ \\
\hline $\begin{array}{l}150-1200 \\
150-150\end{array}$ & $\begin{array}{l}243 \cdot 5^{* *} \\
235 \cdot 7^{* *}\end{array}$ & $\begin{array}{l}17 \cdot 26 \\
15 \cdot 74\end{array}$ & $\begin{array}{l}8 \cdot 9^{* *} \\
8 \cdot 5^{* *}\end{array}$ & $\begin{array}{l}0.41 \\
0.38^{* *}\end{array}$ & $\begin{array}{l}0.77 \\
0.78\end{array}$ \\
\hline $\begin{array}{l}75-1200 \\
75-75\end{array}$ & $\begin{array}{l}248 \cdot 8 \\
244 \cdot 5^{* *}\end{array}$ & $\begin{array}{l}17.01 \\
17 \cdot 31\end{array}$ & $\begin{array}{l}9 \cdot 0^{* *} \\
8 \cdot 2^{* *}\end{array}$ & $\begin{array}{l}0.46 \\
0.41\end{array}$ & $\begin{array}{l}0.73 \\
0.82\end{array}$ \\
\hline $\begin{array}{l}0-1200 \\
0-0\end{array}$ & $\begin{array}{l}222 \cdot 9^{* * \dagger} \\
176 \cdot 4^{* *}\end{array}$ & $\begin{array}{r}15.76 \\
9.39\end{array}$ & $\begin{array}{l}8 \cdot 4^{* *} \dagger \\
4 \cdot 9^{* *}\end{array}$ & $\begin{array}{l}0.45 \dagger \\
0.34^{* *}\end{array}$ & $\begin{array}{l}0 \cdot 72 \\
0 \cdot 62^{* *}\end{array}$ \\
\hline $\begin{array}{l}\text { Pooled SE } \\
P \text { values for trend effects } \| \\
\text { Previous vitamin A intake }\end{array}$ & 6.9 & - & $0 \cdot 3$ & 0.02 & 0.03 \\
\hline $\begin{array}{l}\text { L term } \\
\text { Q term } \\
\text { Supplemental vitamin A: } \\
\text { Interaction: }\end{array}$ & $\begin{array}{r}<0.001 \\
<0.001 \\
0.001 \\
0.004\end{array}$ & $\begin{array}{l}- \\
- \\
-\end{array}$ & $\begin{array}{l}<0.001 \\
<0.001 \\
<0.001 \\
<0.001\end{array}$ & $\begin{array}{l}<0.001 \\
>0.05 \\
0.007 \\
0.002\end{array}$ & $\begin{array}{c}<0.001 \\
0.021 \\
>0.05 \\
0.016\end{array}$ \\
\hline
\end{tabular}

RE, retinol equivalents.

Mean values were significantly different from those of the control group, ${ }^{* *} P<0.00625$, or from those of the group that had been fed on the same diet until day $0, \dagger P<0.0125$ (Student's $t$ test).

‡ For details of diets and procedures, see Table 1 and pp. 624-629.

$\S$ Feed intake was measured per cage with four animals from day 0 to 10 ; the pooled sE was not calculated because of the low number of degrees of freedom.

$\|$ Values for linear (L) and/or quadratic (Q) term in effects of previous vitamin A intake (before day 0 ) and supplemental vitamin A. Only the groups with dietary vitamin A concentrations lower than $1200 \mathrm{RE} / \mathrm{kg}$ feed before day 0 were included.

A intake significantly affected haemoglobin, packed cell volume and erythrocyte count. For the reference group ( $n 8)$ which received the diet with $1200 \mathrm{RE}$ and $35 \mathrm{mg} \mathrm{Fe} / \mathrm{kg}$ throughout, the values at day 10 were: haemoglobin, $9 \cdot 2 \mathrm{mmol} / 1$; packed cell volume, $44 \cdot 6 \%$; erythrocyte count, $6 \cdot 6810 \mathrm{E} 12 / 1$; mean cell volume, $66 \cdot 9 \mathrm{fl}$.

\section{Plasma iron and total iron-binding capacity}

At the end of the supplementation trial (day 10), total Fe-binding capacity was depressed in the groups given either 0 or $75 \mathrm{RE} / \mathrm{kg}$ throughout the experiment (Table 7). The group given the retinol-free diet was most seriously affected and this was associated with a low plasma $\mathrm{Fe}$ concentration. Vitamin A repletion produced a significant rise in total $\mathrm{Fe}$ binding capacity. Transferrin saturation was not affected by vitamin A intake (Table 7). Previous vitamin A intake significantly affected plasma $\mathrm{Fe}$ concentration and total $\mathrm{Fe}$ binding capacity. The reference group $(n 8)$, which received the adequate diet throughout, showed the following values: plasma $\mathrm{Fe}, 32.30 \mu \mathrm{mol} / 1$; total Fe-binding capacity, $88.05 \mu \mathrm{mol} / 1$; transferrin saturation, $36.82 \%$. 


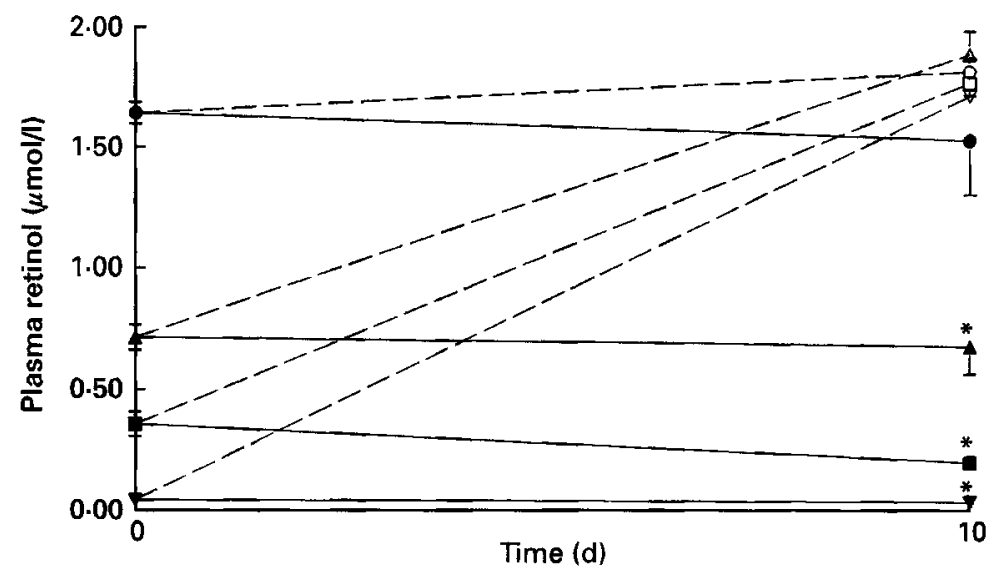

Fig. 2. Plasma retinol concentrations at days 0 and 10 (Fig. 1).(O), 450 retinol equivalents (RE)/ $\mathrm{kg}$ feed; (A), $150 \mathrm{RE} / \mathrm{kg}$ feed; ( $\square), 75 \mathrm{RE} / \mathrm{kg}$ feed and $(\nabla), 0 \mathrm{RE} / \mathrm{kg}$ feed before supplementation. All diets were iron sufficient from day 0 , but only half of the groups were supplemented with vitamin A to a dietary level of $1200 \mathrm{RE} / \mathrm{kg}$ feed. Dotted lines and open symbols at day 10 refer to vitamin A supplemented groups. Values are means with their standard errors indicated by vertical bars. Values were log-transformed before they were analysed statistically. Trend analysis revealed significant linear and quadratic terms of vitamin A intake before day $0(P<0.001)$ for values at both day 0 and day 10 of vitamin A supplementation $(P<0.001)$ and of interaction of these effects $(P$ $<0.001$ ) for the values at day 10 . ${ }^{*}$ Mean values were significantly different from those for the group fed on the same diet before day $0: P<0.001$.

Table 5. Liver retinol concentrations at day 10 in rats fed on diets containing different levels of vitamin $A^{*}$

(Mean values with their standard errors for eight animals per group)

\begin{tabular}{|c|c|c|}
\hline \multirow{2}{*}{$\begin{array}{l}\text { Dietary vitamin } \mathrm{A} \text { (before day } \\
0 \text { - after day } 0, \mathrm{RE} / \mathrm{kg} \text { ) }\end{array}$} & \multicolumn{2}{|c|}{$\begin{array}{c}\text { Liver retinol } \\
\text { (nmol } / \mathrm{g} \text { liver wet } \mathrm{wt} \text { ) }\end{array}$} \\
\hline & Mean & $\mathrm{SE}$ \\
\hline $1200-1200$ (control) & $60 \cdot 7$ & $2 \cdot 9$ \\
\hline $\begin{array}{l}450-1200 \\
450-450\end{array}$ & $\begin{array}{r}23 \cdot 3 \\
6 \cdot 1\end{array}$ & $\begin{array}{l}3 \cdot 2 \\
0 \cdot 7\end{array}$ \\
\hline $\begin{array}{l}150-1200 \\
150-150\end{array}$ & $\begin{array}{l}150 \\
\text { ND }\end{array}$ & 0.8 \\
\hline $\begin{array}{l}75-1200 \\
75-75\end{array}$ & $\begin{array}{l}13 \cdot 2 \\
\text { ND }\end{array}$ & $2 \cdot 6$ \\
\hline $\begin{array}{l}0-1200 \\
0-0\end{array}$ & $\begin{array}{l}11 \cdot 9 \\
\text { ND }\end{array}$ & $1 \cdot 6$ \\
\hline
\end{tabular}

RE, retinol equivalents; ND, not detectable (the detection limit is about $3 \mathrm{nmol} / \mathrm{g}$ wet liver weight).

* For details of diets and procedures, see Table 1 and pp. 624-629.

\section{Iron in organs}

Liver Fe concentrations at the end of the supplementation trial were similar for all groups (Table 8). In the groups given diets with either 75,150 or $450 \mathrm{RE} / \mathrm{kg}$ there were decreases in kidney $\mathrm{Fe}$ concentrations when compared with the control group. Vitamin $\mathrm{A}$ supplementation raised kidney Fe concentration in the group that had been fed on the diet with $75 \mathrm{RE} / \mathrm{kg}$ until day 0 . Decreasing vitamin A intakes in the groups not supplemented with vitamin $\mathrm{A}$ were associated with increases in spleen and tibia Fe concentrations. The 
Table 6. Haematological characteristics at day 10 in rats fed on diets containing different levels of vitamin $A \ddagger$

(Mean values with their pooled standard errors for eight animals per group; the calculation of the pooled SE included the reference group)

\begin{tabular}{|c|c|c|c|c|}
\hline $\begin{array}{l}\text { Dietary vitamin } A \text { (before day } \\
0 \text { - after day } 0, \mathrm{RE} / \mathrm{kg} \text { ) }\end{array}$ & $\begin{array}{l}\text { Haemoglobin } \\
(\mathrm{mmol} / \mathrm{l})\end{array}$ & $\begin{array}{l}\text { Packed cell } \\
\text { volume } \\
(\%)\end{array}$ & $\begin{array}{c}\text { Erythrocyte } \\
\text { count } \\
(10 \mathrm{E} 12 / 1)\end{array}$ & $\begin{array}{l}\text { Mean cell } \\
\text { volume } \\
\text { (fi) }\end{array}$ \\
\hline $1200-1200$ (control) & $8 \cdot 7$ & $42 \cdot 7$ & $6 \cdot 82$ & $62 \cdot 6$ \\
\hline $\begin{array}{l}450-1200 \\
450-450\end{array}$ & $\begin{array}{l}8 \cdot 8 \\
8 \cdot 8\end{array}$ & $\begin{array}{l}43 \cdot 7 \\
44 \cdot 0\end{array}$ & $\begin{array}{l}6 \cdot 81 \\
6 \cdot 73\end{array}$ & $\begin{array}{l}64 \cdot 3 \\
65 \cdot 4\end{array}$ \\
\hline $\begin{array}{l}150-1200 \\
150-150\end{array}$ & $\begin{array}{l}8 \cdot 8 \\
8 \cdot 8\end{array}$ & $\begin{array}{l}43 \cdot 7 \\
43 \cdot 4\end{array}$ & $\begin{array}{l}6 \cdot 79 \\
6 \cdot 88\end{array}$ & $\begin{array}{l}64 \cdot 4 \\
63 \cdot 2\end{array}$ \\
\hline $\begin{array}{l}75-1200 \\
75-75\end{array}$ & $\begin{array}{l}8 \cdot 4 \dagger \\
9 \cdot 0\end{array}$ & $\begin{array}{l}41 \cdot 8 \\
44 \cdot 6\end{array}$ & $\begin{array}{l}6.66 \\
7.07\end{array}$ & $\begin{array}{l}62 \cdot 9 \\
63 \cdot 1\end{array}$ \\
\hline $\begin{array}{l}0-1200 \\
0-0\end{array}$ & $\begin{array}{l}8 \cdot 5 \dagger \\
9 \cdot 4^{* *}\end{array}$ & $\begin{array}{l}42 \cdot 2 \dagger \\
45 \cdot 9 * *\end{array}$ & $\begin{array}{l}6.86 \dagger \\
7.83^{* * *}\end{array}$ & $\begin{array}{l}61 \cdot 7 \dagger \\
58 \cdot 6^{* *}\end{array}$ \\
\hline $\begin{array}{l}\text { Pooled SE } \\
P \text { values for trend effects } \$\end{array}$ & $0 \cdot 1$ & $0 \cdot 8$ & $0 \cdot 14$ & 0.8 \\
\hline $\begin{array}{l}\text { Previous vitamin A intake } \\
\text { L term } \\
\text { Q term } \\
\text { Supplemental vitamin A } \\
\text { Interaction }\end{array}$ & $\begin{aligned}> & 0.05 \\
> & 0.05 \\
< & 0.001 \\
& 0.001\end{aligned}$ & $\begin{aligned}> & 0.05 \\
> & 0.05 \\
& 0.004 \\
& 0.025\end{aligned}$ & $\begin{array}{l}0.001 \\
0.003 \\
0.001 \\
0.001\end{array}$ & $\begin{aligned}< & 0.001 \\
& 0.002 \\
> & 0.05 \\
> & 0.05\end{aligned}$ \\
\hline
\end{tabular}

RE, retinol equivalents.

Mean values were significantly different from those of the control group, ${ }^{* *} P<0.00625$, or from those of the group that had been fed on the same diet until day $0, \dagger P<0.0125$ (Student's $t$ test).

$\ddagger$ For details of diets and procedures, see Table 1 and pp. 624-629.

$\S$ Values for linear (L) and/or quadratic (Q) term in effects of previous vitamin A intake (before day 0 ) and supplemental vitamin A. Only the groups with dietary vitamin A concentrations lower than $1200 \mathrm{RE} / \mathrm{kg}$ feed before day 0 were included.

concentrations of $\mathrm{Fe}$ in spleen and tibia were generally reduced in response to vitamin $\mathrm{A}$ supplementation (Table 8). Thus in the trend analysis previous vitamin $A$ intake and vitamin A supplementation were found to reduce significantly spleen and tibia Fe concentrations. The reference group $(n 8)$ had the following organ Fe concentrations $(\mu \mathrm{mol} / \mathrm{g}$ dry weight): liver, $3 \cdot 33$; spleen, $14 \cdot 22$; kidney, $4 \cdot 49$; tibia, $1 \cdot 39$.

\section{DISCUSSION}

After Fe depletion for $14 \mathrm{~d}$, the rats with different vitamin A status were repleted with $\mathrm{Fe}$ without or with supplemental vitamin A. This experimental design allowed us to examine the effect of vitamin A supplementation on Fe-induced regeneration of Fe status as influenced by the degree of chronic vitamin-A deficiency. The baseline of the experiment (day 0) may simulate the situation in humans with anaemia in areas where marginal vitamin $A$ intake is a problem. The additional effect of supplemental vitamin A on Fe status after Fe supplementation, as has been shown in two independent studies with children and pregnant women (Mejía \& Chew, 1988; Suharno et al. 1993), can now be described in more detail.

Fe repletion raised the selected haematological variables as would be anticipated (Forbes et al. 1989). Vitamin A repletion of the vitamin A-deficient rats clearly improved their 
Table 7. Plasma iron, total iron-binding capacity and percentage transferrin saturation at day 10 in rats fed on diets containing different levels of vitamin $A \ddagger$

(Mean values with their pooled standard errors for eight animals per group; calculation of the pooled SE included the reference group)

\begin{tabular}{|c|c|c|c|}
\hline $\begin{array}{l}\text { Dietary vitamin } A \text { (before day } \\
0 \text { - after day } 0, \mathrm{RE} / \mathbf{k g} \text { ) }\end{array}$ & $\begin{array}{l}\text { Plasma iron } \\
(\mu \mathrm{mol} / \mathrm{l})\end{array}$ & $\begin{array}{l}\text { Total iron-binding } \\
\text { capacity } \\
(\mu \mathrm{mol} / 1)\end{array}$ & $\begin{array}{c}\text { Transferrin } \\
\text { saturation } \\
(\%)\end{array}$ \\
\hline $1200-1200$ (control) & $40 \cdot 36$ & $95 \cdot 19$ & $42 \cdot 80$ \\
\hline $\begin{array}{l}450-1200 \\
450-450\end{array}$ & $\begin{array}{l}41 \cdot 55 \\
43 \cdot 39\end{array}$ & $\begin{array}{l}89 \cdot 01 \\
90 \cdot 42\end{array}$ & $\begin{array}{l}46 \cdot 71 \\
48 \cdot 19\end{array}$ \\
\hline $\begin{array}{l}150-1200 \\
150-150\end{array}$ & $\begin{array}{l}42 \cdot 51 \\
44 \cdot 13\end{array}$ & $\begin{array}{l}89 \cdot 56 \\
87 \cdot 86\end{array}$ & $\begin{array}{l}47 \cdot 59 \\
50 \cdot 20\end{array}$ \\
\hline $\begin{array}{l}75-1200 \\
75-75\end{array}$ & $\begin{array}{l}37 \cdot 77 \\
39 \cdot 47\end{array}$ & $\begin{array}{l}83 \cdot 71^{* *} \\
86 \cdot 49^{* *}\end{array}$ & $\begin{array}{l}45 \cdot 27 \\
45 \cdot 97\end{array}$ \\
\hline $\begin{array}{l}0-1200 \\
0-0\end{array}$ & $\begin{array}{l}34 \cdot 97 \\
30 \cdot 11^{* *}\end{array}$ & $\begin{array}{l}83 \cdot 17^{* *} \dagger \\
71 \cdot 86^{* *}\end{array}$ & $\begin{array}{l}42 \cdot 30 \\
42 \cdot 40\end{array}$ \\
\hline $\begin{array}{l}\text { Pooled SE } \\
P \text { values for trend effects } \S \\
\text { Previous vitamin A intake }\end{array}$ & $3 \cdot 63$ & $2 \cdot 82$ & 4.91 \\
\hline $\begin{array}{l}\text { L term } \\
\text { Q term } \\
\text { Supplemental vitamin A } \\
\text { Interaction }\end{array}$ & $\begin{array}{l}<0.001 \\
<0.001 \\
>0.05 \\
>0.05\end{array}$ & $\begin{array}{c}0.004 \\
0.003 \\
>0.05 \\
0.002\end{array}$ & $\begin{array}{l}>0.05 \\
>0.05 \\
>0.05 \\
>0.05\end{array}$ \\
\hline
\end{tabular}

RE, retinol equivalents.

Mean values were significantly different from those of the control group, ** $P<0.00625$, or from those of the group that had been fed on the same diet until day $0, \dagger P<0.0125$ (Student's $t$ test).

$\ddagger$ For details of diets and procedures, see Table 1 and pp. 624-629.

$\S$ Values for linear (L) and/or quadratic (Q) term in effects of previous vitamin A intake (before day 0 ) and supplemental vitamin A. Only the groups with dietary vitamin A concentrations lower than $1200 \mathrm{RE} / \mathrm{kg}$ feed before day 0 were included.

vitamin A status as based on plasma and liver retinol concentrations. Supplemental vitamin A significantly influenced $\mathrm{Fe}$ metabolism in the two groups with most severe vitamin A deficiency. At the end of the supplementation period, extra vitamin $\mathbf{A}$ in the diet had reduced blood haemoglobin concentrations, erythrocyte count and packed cell volume. These effects can probably be explained by a diminished haemoconcentration and thus attenuation of the vitamin A-deficiency-induced haemoconcentration as described earlier (Koessler et al. 1926; McLaren et al. 1965; Mejía et al. 1979a, b), and cannot be interpreted as a specific effect of vitamin $\mathrm{A}$ on $\mathrm{Fe}$ metabolism. However, supplemental vitamin $\mathrm{A}$ also raised mean erythrocyte volume in the group previously given the diet without vitamin A. Perhaps this points to a stimulatory effect of vitamin A on erythropoiesis.

Although there was indirect evidence of haemoconcentration in the group fed on the diet without vitamin $\mathrm{A}$, plasma $\mathrm{Fe}$ concentrations and Fe-binding capacity were reduced and were increased after vitamin A supplementation. A low level of plasma $\mathrm{Fe}$ is a consistent feature of poor vitamin A status in children (Mohanram et al. 1977; Bloem et al. 1989) and pregnant women (Suharno et al. 1992). In some human studies (Mejía \& Arroyave, 1982; Bloem et al. 1990), but not all (Mejía \& Chew, 1988; Suharno et al. 1992), low total Febinding capacity or transferrin concentration were associated with poor vitamin A status. Possibly vitamin A controls the synthesis of transferrin, which is the major Fe transport protein carrying $\mathrm{Fe}$ from the storage depots such as liver to the erythropoietic system in 
Table 8. Iron concentrations in organs at day 10 in rats fed on diets containing different levels of vitamin $A \ddagger$

(Mean values with their pooled standard errors for eight animals per group; calculation of the pooled SE included the reference group)

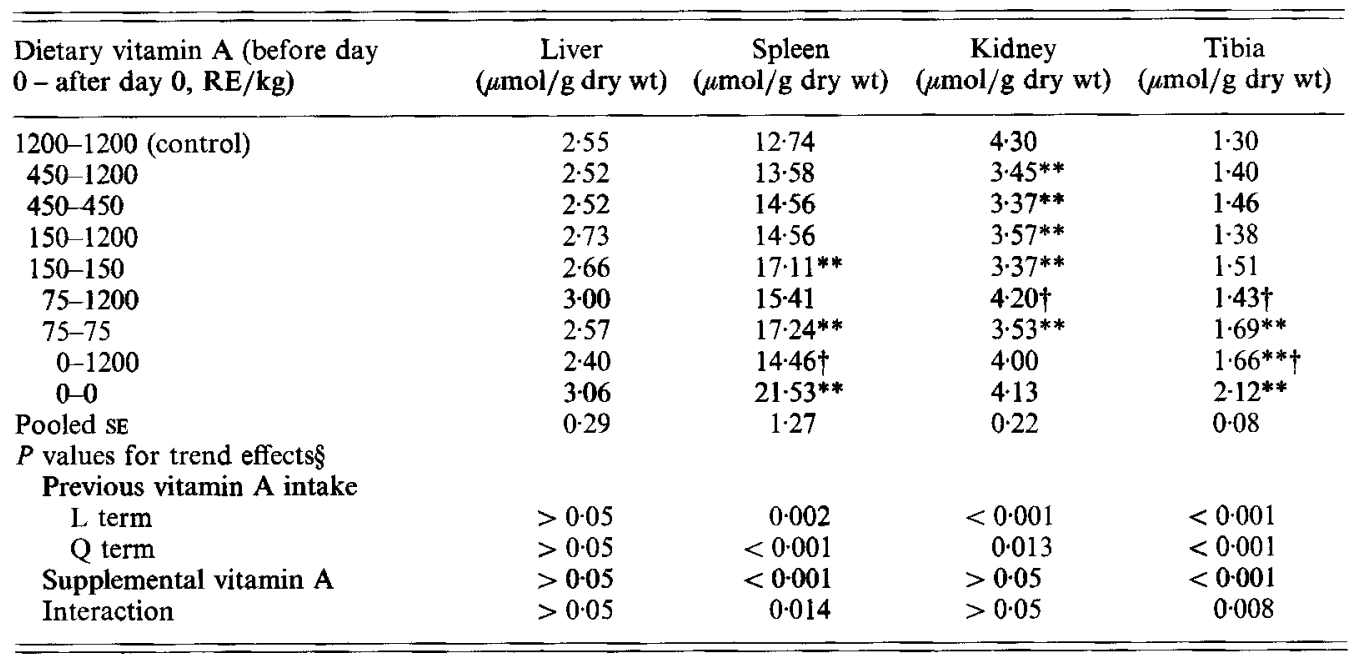

RE, retinol equivalents.

Mean values were significantly different from those of the control group, ** $P<0.00625$, or from those of the group that had been fed on the same diet until day $0, \dagger P<0.0125$ (Student's $t$ test).

$\ddagger$ For details of diets and procedures, see Table 1 and pp. 624-629.

$\$$ Values for linear (L) and/or quadratic (Q) term in effects of previous vitamin A intake (before day 0 ) and supplemental vitamin A. Only the groups with dietary vitamin A concentrations lower than $1200 \mathrm{RE} / \mathrm{kg}$ feed before day 0 were included.

bone marrow. An impaired transferrin synthesis in vitamin A deficiency is compatible with the observation that vitamin $\mathrm{A}$ is involved in the synthesis of the glycosyl moieties of the transferrin molecule (Chan \& Wolf, 1987). In any event, the present study shows that in rats with $\mathrm{Fe}$ deficiency with the highest degree of vitamin A deficiency, supplemental vitamin $\mathrm{A}$ had a raising effect on plasma $\mathrm{Fe}$ and total Fe-binding capacity that was superimposed on that of Fe supplementation. This observation illustrates the involvement of vitamin A in Fe metabolism.

A major advantage of our study with rats is that it provides information on the effects of supplemental vitamin $\mathrm{A}$ on the distribution of $\mathrm{Fe}$ between organs. Liver $\mathrm{Fe}$ concentrations were unchanged after feeding the vitamin A-deficient diets but the reduction in liver weight resulted in a decreased total liver Fe content. A decreased total amount of $\mathrm{Fe}$ in the liver of vitamin A-deficient rats has been found earlier in this laboratory (Sijtsma et al. 1993; Roodenburg et al. 1994). Vitamin A supplementation of the group previously fed on the diet without vitamin A reduced liver Fe concentration but significantly raised total liver Fe content. In the vitamin A-deficient animals there was an increase of splenic and tibia Fe as found earlier (Mejia et al. 1979a, b; Roodenburg et al. 1994). The present study showed that during Fe repletion supplemental vitamin A lowered Fe contents of spleen and tibia. This effect of vitamin A was greater with increasing severity of the previous vitamin A deficiency.

We speculate that in vitamin A deficiency blood cell synthesis is impaired leading to increased $\mathrm{Fe}$ stores in the macrophages in tibia and spleen, this process possibly being 
enhanced by increased destruction of inferior erythrocytes. In addition Fe mobilization might be impaired because $\mathrm{Fe}$ is trapped in the macrophages. The effects of vitamin $\mathrm{A}$ deficiency on Fe metabolism can be reversed by supplemental vitamin A. This reasoning could explain why supplemental vitamin A contributes to recovery from Fe deficiency associated with vitamin A deficiency.

In conclusion, the outcome of the present experiment carried out with rats under strictly controlled conditions mimics the observation (Mejía \& Chew, 1988; Suharno et al. 1993) in humans with marginal vitamin $\mathrm{A}$ intake that vitamin $\mathrm{A}$ together with $\mathrm{Fe}$ is more effective in normalizing $\mathrm{Fe}$ status than is Fe supplementation alone. This study indicates that vitamin A supplementation under those conditions stimulates the utilization of Fe stores in spleen and bone.

The authors thank Gerrit van Tintelen, Inez Lemmens, Frank van den Broek and Jan Burema for their assistance. This study was supported by funding from the Dutch Ministry of Education and Science to the Human Nutrition Biology Graduate Training Network.

\section{REFERENCES}

Amine, E. K., Corey, J., Hegsted, D. M. \& Hayes, K. C. (1970). Comparative hematology during deficiencies of iron and vitamin $A$ in the rat. Journal of Nutrition 100, 1033-1040.

Bloem, M. W., Wedel, M., Egger, R. J., Speek, A. J., Schrijver, J., Saowakontha, S. \& Schreurs, W. H. P. (1989). Iron metabolism and vitamin deficiency in children in Northeast Thailand. American Journal of Clinical Nutrition 50, 332-338.

Bloem, M. W., Wedel, M., van Agtmaal, E., Speek, A. J., Saowakontha, S. \& Schreurs, W. H. P. (1990). Vitamin A intervention: short-term effects of a single, oral massive dose on iron metabolism. American Journal of Clinical Nutrition 51, 76-79.

Chan, V. T. \& Wolf, G. (1987). The role of vitamin A in the glycosylation reactions of glycoprotein synthesis in an 'in vitro' system. Biochemical Journal 247, 53-62.

Forbes, A. L., Adams, C. E., Arnaud, M. J., Chichester, C. O., Cook, J. D., Harrison, B. N., Hurrell, R. F,, Kahn, S. G., Morris, E. R., Tanner, J. T. \& Whittaker, P. (1989). Comparison of in vitro, animal and clinical determinations of iron bioavailability: International Nutritional Anemia Consultative Group Task Force report on iron availability. American Journal of Clinical Nutrition 49, 225-238.

Koessler, K. K., Maurer, S. \& Loughlin, R. (1926). The relation of anaemia, primary and secondary, to vitamin A deficiency. Journal of the American Medical Association 87, 476-482.

McLaren, D. S., Tchalian, M. \& Ajans, Z. A. (1965). Biochemical and hematologic changes in the vitamin A deficient rat. American Journal of Clinical Nutrition 17, 131-138.

Mejia, L. A. \& Arroyave, G. (1982). The effect of vitamin A fortification of sugar on iron metabolism in preschool children in Guatemala. American Journal of Clinical Nutrition 36, 87-93.

Mejía, L. A. \& Chew, F. (1988). Hematological effect of supplementing anemic children with vitamin $A$ alone and in combination with iron. American Journal of Clinical Nutrition 48, 595-600.

Mejía, L. A., Hodges, R. E. \& Rucker, R. B. (1979a). Clinical signs of anaemia in vitamin A-deficient rats. American Journal of Clinical Nutrition 32, 1439-1444.

Mejía, L. A., Hodges, R. E. \& Rucker, R. B. (1979b). Role of vitamin A in the absorption, retention and distribution of iron in the rat. Journal of Nutrition 109, 129-137.

Mohanram, M., Kulkarni, K. A. \& Reddy, V. (1977). Hematological studies in vitamin A deficient children. International Journal of Vitamin and Nutrition Research 47, 389-393.

Muhilal, Permeisih, D., Idjradinata, Y. R., Muherdiyantiningsih \& Karyadi, D. (1988). Vitamin A-fortified monosodium glutamate and health, growth, and survival of children: a controlled field trial. American Journal of Clinical Nutrition 48, 1271-1276.

National Research Council (1978). Nutrient Requirements of Laboratory Animals. Washington, DC: National Academy of Sciences.

Roodenburg, A. J. C., West, C. E., Yu, S. \& Beynen, A. C. (1994). Comparison between time-dependent changes in iron metabolism of rats as induced by marginal deficiency of either vitamin A or iron. British Journal of Nutrition 71, 687-699.

Sijtsma, K. W., Van den Berg, G. J., Lemmens, A. G., West, C. E. \& Beynen, A. C. (1993). Iron status in rats fed on diets containing marginal amounts of vitamin A. British Journal of Nutrition 70, 777-785.

Sklan, D., Harlevy, O. \& Donoghue, S. (1986). The effect of different dietary levels of vitamin A on metabolism of copper, iron and zinc in the chick. International Journal for Vitamin and Nutrition Research 57, 11-18. 
Snedecor, G. W. \& Cochran, W. G. (1980). Statistical Methods, 7th ed., pp. 239-240. Ames: Iowa State University Press.

Staab, D. B., Hodges, R. E., Metcalf, W. K. \& Smith, J. L. (1984). Relationship between vitamin A and iron in the liver. Journal of Nutrition 114, 840-844.

Suharno, D., West, C. E., Muhilal, Logman, M. H. G. M., de Waart, F. G., Karyadi, D. \& Hautvast, J. G. A. J. (1992). Cross sectional study on the iron and vitamin A status of pregnant women in West Java, Indonesia. American Journal of Clinical Nutrition 56, 988-993.

Suharno, D., West, C. E., Muhilal, Karyadi, D. \& Hautvast, J. G. A. J. (1993). Not only supplementation with iron but also with vitamin $\mathbf{A}$ is necessary to combat nutritional anaemia in pregnant women in West Java, Indonesia. Lancet 342, 1325-1328.

Van Herck, H., Baumans, V., De Boer, S. F., Van Der Gugten, J., Van Woerkom, A. B. \& Beynen, A. C. (1991). Endocrine stress response in rats subjected to singular orbital puncture while under diethyl-ether anaesthesia. Laboratory Animals 25, 325-329.

Van Herck, H., Baumans, V., Van Der Craats, N. R., Hesp, A. P. M., Meijer, G. W., Van Tintelen, G., Walvoort, H. C. \& Beynen, A. C. (1992). Histological changes in the orbital region of rats after orbital puncture. Laboratory Animals 26, 53-58.

Wolde-Gebriel, Z., Haile Gebru, Fisseha, T. \& West, C. E. (1993a). Vitamin A, iron and iodine status in children with severe vitamin A deficiency in a rural village in Hararge Region of Ethiopia. European Journal of Clinical Nutrition 47, 104-114.

Wolde-Gebriel, Z., West, C. E., Haile Gebru, Tadesse, A. S., Fisseha, T., Gabre, P., Ayana, G. \& Hautvast, J. G. A. J. (1993b). Interrelationship between vitamin A, iodine and iron status in schoolchildren in Shoa Region, Central Ethiopia. British Journal of Nutrition 70, 593-607. 